\title{
Extraction, Purification and Spectroscopic Characterization of Phycobiliproteins Extracted from some Nostoc Spp. Mervat H. Hussein $^{1}$; Noura E. El-Naggar ${ }^{2}$ and Asmaa A. El-Sawah ${ }^{1}$ \\ ${ }^{1}$ Botany Dept., Fac. of Sci., Mansoura Univ., Mansoura, Egypt \\ ${ }^{2}$ Dept. of Bioprocess Development, Genetic Engin. and Biotechnol. Res. Inst.,, City of Scientific Res. and Technol. Appl., Alexandria, Egypt
}

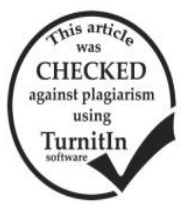

\section{ABSTRACT}

Phycocyanin and phycoerythrin are considered the major phycobiliprotein in many cyanobacteria as well as being a secondary phycobiliprotein in some red algae. In this article, the biomass of Nostoc linckia was harvested at the $16^{\text {th }}$ day, which approximately equalled $361 \mathrm{mg} / \mathrm{L}$ dry biomass for attaining the maximum content of phycocyanin, and the biomass of Nostoc carneum was collected at the $17^{\text {th }}$ day that approximately equalled $326 \mathrm{mg} / \mathrm{L}$ dry biomass for attaining the maximum content of phycoerythrin. Phycocyanin and phycoerythrin were extracted from both Nostoc linckia and Nostoc carneum respectively. They were extracted by successive cycles of freezing and thawing using $50 \mathrm{mM}$ phosphate buffer solution $(\mathrm{pH} 7)$ then purified by single step of precipitation in $65 \%$ of ammonium sulphate. Phycocyanin and phycoerythrin achieved 2.29 and 3.02 of purity ratio; respectively. The purified phycocyanin and phycoerythrin exhibited maximum absorbance at 614 and $560 \mathrm{~nm}$ respectively. Keywords: Nostoc spp. growth, phycobiliproteins, phycocyanin, phycoerythrin, extraction, purification ratio, characterization

\section{INTRODUCTION}

Cyanobacteria are a division descending from algae. Cyanobacteria are considered the only known oxygen photobacteria prokaryotes. Cyanobacteria are unicellular or multicellular oxygenic photoautotrophs prokaryotes that are found in almost every possible habitat on earth possess chlorophyll (a) and perform oxygenic photosynthesis associated with photosystems I and II (Castenholz and Waterbury, 1989; Garcia-Pichel and Pringault, 2001).

In the last few years, the variety and physiology of cyanobacteria have acquired great interest as a rich source of bioactive compounds that serves as an excellent base for discovering their biotechnological applications. (Bhadury et al. 2004; Abed et al. 2009). Cyanobacterial genera as Microcystis, Anabaena, Nostoc and Oscillatoria provide a wide range of secondary metabolites, consequently they are considered as promising microalgae for production of bioactive natural products (Singh et al., 2017).

Phycobiliproteins are monophyletic family of homologous heterodimeric proteins which consist of a globin-type core that carries the chromophores (the lightcapturing part) which are the most important constituents of the phycobilisomes, and an N-terminal extension that is mainly involved in oligomerization (Schmidt et al., 2007). Phycocyanin and allophycocyanin are two pigmentproteins which universally found in all cyanobacteria and red algae studied (Gantt et al., 1979), while phycoerythrin is a variable component and its presence in the phycobilisomes of certain organisms is depending on the light conditions, particularly the quality of light available (Tandeau de Marsac, 1977).

Aim: Extraction, purification and spectroscopic characterization of both phycocyanin and phycoerythrin from Nostoc linckia and Nostoc carneum; respectively.

\section{MATERIALS AND METHODS}

Isolation, purification and identification of cyanobacterial isolates

Nostoc carenum and Nostoc linckia were isolated from garden soil samples in Dakahlia, Egypt. Culture purification was according to Hoshaw \& Rosowski (1973). Identification of Nostoc carenum and Nostoc linckia were approved with the standard ones according to Bornet \&
Flahault (1886); Desikachary (1959). The two cyanobacteria were grown in axenic culture at $28 \pm 2{ }^{\circ} \mathrm{C}$ for 21 days incubation period under continuous illumination 3200 lux in $500 \mathrm{ml}$ conical flasks containing $200 \mathrm{ml}$ BG-11 medium (Stainer et al., 1971) \& (Rippka et al., 1979), adjusting pH at 7 .

Determination of growth (dry biomass)

From each cyanobacterium, biomass was harvested at 3 days intervals through incubation period ( 21 days) by self-sedimentation then filtered by a glass fiber filter paper. The biomass was washed once with dist. water and filtered again. This collected biomass was dried in an electric oven at about $60^{\circ} \mathrm{C}$.

\section{Extraction of phycobiliproteins}

From each cyanobacterium, biomass was harvested by self-sedimentation then filtered by a glass fiber filter paper. The biomass was washed once with dist. water and filtered again. This collected biomass was referred to as the wed biomass which was kept in freezing at $-20^{\circ} \mathrm{C}$ for extracting biliproteins. After the incubation at $28 \pm 2{ }^{\circ} \mathrm{C}$ for 21 days under continuous illumination 3200 lux, the fresh biomass was collected at the beginning of the stationary phase. Phycocyanin (PC) and phycoerythrin (PE) are pigment-protein complexes from the light-harvesting phycobiliprotein of cyanobacteria, which will be used in the biosynthesis of silver nanoparticles (AgNPs). They were extracted at the beginning of the stationary phase by taking the fresh biomass of 1 litre culture which corresponding to $361 \mathrm{mg} / \mathrm{L}$ dry biomass of Nostoc carenum and corresponding to $326 \mathrm{mg} / \mathrm{L}$ dry biomass of Nostoc linckia. Biliproteins containing cultures were harvested by centrifugation at $4,000 \mathrm{rpm}$ for $10 \mathrm{~min}$. then the biomass pellets washed twice with distilled water. The washed biomass for each cyanobacterium added to $25 \mathrm{ml}$ of $50 \mathrm{mM}$ phosphate buffer $(\mathrm{pH} 7)$, then subjected to freezing $\left(-20^{\circ} \mathrm{C}\right)$ and thawing at room temperature. PC was extracted by 5 cycles of repeated freezing and thawing, however PE needed 6 cycles for complete diffusion of pigments. The biomass residue was discarded by centrifugation at $4000 \mathrm{rpm}$ for 10 min. and supernatant containing biliproteins extract was collected and termed as crude extract.

Purification of phycobiliproteins

The crude extract was further purified by single step of precipitation using $65 \%\left(\mathrm{NH}_{4}\right)_{2} \mathrm{SO}_{4}$ after the method of 
Chakdar and Pabbi (2012), where it was mixed thoroughly with the biomass extract and kept $12 \mathrm{~h}$ at $4^{\circ} \mathrm{C}$. Biomass pellets were recovered by centrifugation (HERMEL Z32 $\mathrm{HK}$ ) at $4000 \mathrm{rpm}$ for $30 \mathrm{~min}$. at $4^{\circ} \mathrm{C}$ and dissolved in $10 \mathrm{~mL}$ of $(50 \mathrm{mM})$ phosphate buffer. The purity index of homogenate was checked by detectiing the absorption spectra.

\section{Determination of phycobiliproteins}

$\mathrm{PE}$ and $\mathrm{PC}$ concentration and the purity ratio were estimated by (Bennett and Bogorad 1973) equations:

\section{RESULTS}

\section{Growth curve of Nostoc linckia}

The results showed that Nostoc linckia growth in BG-11 medium (photo 1) increased progressively with a lag phase of 3 days (Table 1) followed by the exponential phase till reached the stationary phase on $24^{\text {th }}$ day.

Table 1. Growth curve of Nostoc linckia

\begin{tabular}{lc}
\hline $\begin{array}{l}\text { Parameter } \\
\text { Days }\end{array}$ & $\begin{array}{c}\text { Dry weight } \\
\text { (mg/L) }\end{array}$ \\
\hline 3 & $46 \pm 8$ \\
6 & $91.66 \pm 13$ \\
9 & $142 \pm 13$ \\
12 & $227 \pm 15$ \\
15 & $325.8 \pm 12$ \\
18 & $401 \pm 15$ \\
21 & $425 \pm 8$ \\
24 & $404 \pm 9$ \\
\hline
\end{tabular}

\section{Growth curve of Nostoc carenum}

The results showed that Nostoc carneum growth in BG-11 medium increased steadily with a lag phase of 6 days (Table 2) followed by the logarithmic phase till attained the stationary phase on $24^{\text {th }}$ day.

\begin{tabular}{lc}
$\begin{array}{l}\text { Table 2. Growth curve of Nostoc carneum } \\
\text { Parameter }\end{array}$ & $\begin{array}{c}\text { Dry weight } \\
\text { (mg/L) }\end{array}$ \\
Days & $56 \pm 9$ \\
\hline 3 & $83 \pm 11$ \\
6 & $122 \pm 11$ \\
9 & $154 \pm 12$ \\
12 & $226 \pm 9.5$ \\
15 & $349 \pm 14$ \\
18 & $398 \pm 6.9$ \\
21 & $404 \pm 10$ \\
\hline
\end{tabular}

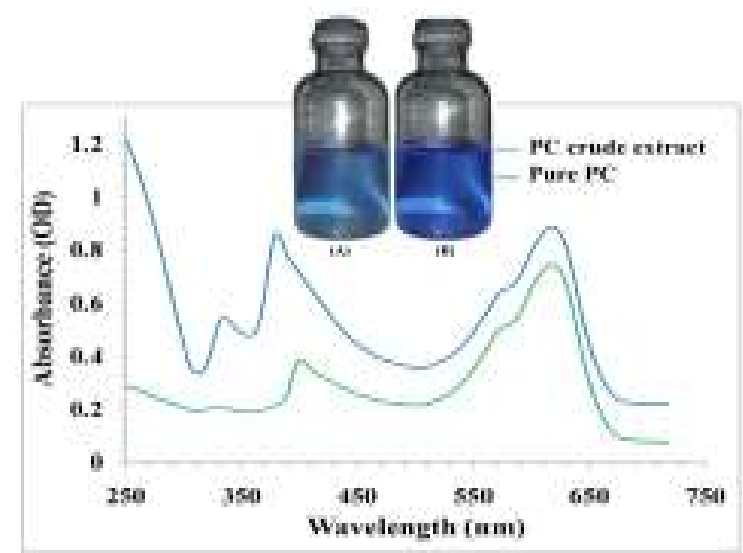

Fig. 1. UV-Vis absorption spectra of PC crude extract (A) and purified PC (B), where $\lambda_{A}$ $\max =614 \mathrm{~nm}$

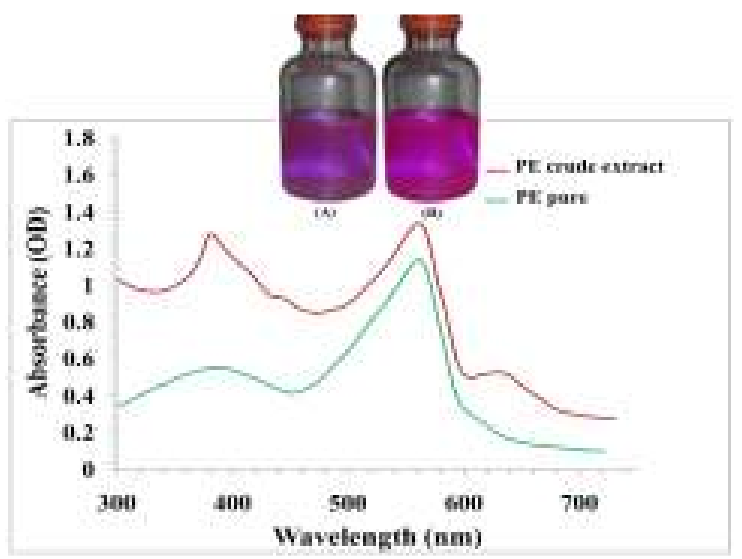

Fig. 2. UV-Vis absorption spectra of PE crude extract (A) and purified PE (B), where $\lambda_{A}$ $\max =560 \mathrm{~nm}$

Extraction, purification and spectral analysis of the phycobiliproteins

The used protocol of extraction and purification is efficient enough to obtain high purity of PC and PE. The purity ratio and conc. of PC are 2.29 and 0.114 $\mathrm{mg} / \mathrm{mL}$; respectively showed in Fig. 1 . The purity ratio and conc. of $\mathrm{PE}$ are 3.02 and $0.111 \mathrm{mg} / \mathrm{mL}$; respectively showed in Fig. 2.

\section{DISCUSSION}

In cyanobacteria, light is harvested by phycobiliprotein. The synthesis of phycobiliprotein depends on the provided environmental nitrogen and these phycobiliproteins may act as a nitrogen store (Tandeau de Marsac and Houmard, 1993). Therefore, cyanobacteria need a nitrogen source for growth that presented in ammonium, nitrate and nitrite (Guerrero and Lara, 1987). In this study, the biomass of Nostoc linckia was harvested at the $16^{\text {th }}$ day, which approximately equalled $361 \mathrm{mg} / \mathrm{L}$ dry biomass for attaining the maximum content of phycocyanin, and the biomass of Nostoc carneum was collected at the $17^{\text {th }}$ day that approximately equalled $326 \mathrm{mg} / \mathrm{L}$ dry biomass for attaining the maximum content of phycoerythrin. Hussein et al. (2000) studied different species of cyanobacteria: Calothrix marchica, Cylindrospermum muscicola var. longispora, Anabaena fertilissima, Tolipothrix bouteillei and Nostoc muscorum and recorded their maximum content of total biliprotein, phycocyanin, allophycocyanin, phycoerythrin and total pigment. They documented that the phycobiliprotein is considered $50 \%$ of the total protein at which C-phycocyanin level reaches to $17 \%$ of the dry weight and allophycocyanin reaches to $11 \%$ of dry weight. Phycocyanin in some Anabaena and Nostoc spp. is the main pigment while in other Nostoc spp. can only reach to $10 \%$ of dry weight according to Moreno et al. (1995). Phycocyanin of various cyanobacteria reached their highest values at the $10^{\text {th }}$ day of incubation of $A$. fertilissima and $N$. muscorum, $14^{\text {th }}$ day for C. marchica and T. bouteillei while Cyl. muscicola var. longispora needed $16^{\text {th }}$ day (Hussein, et al. 2000).

Extraction, Purification, and Spectral analysis of the phycobiliproteins

Freeze thaw method has been selected for extraction of phycobiliproteins, because it has many 
advantages over other methods, which are not reproductive, low yielding, and probably could destroy the characteristic fluorescence properties of the protein (Soni et al., 2006). The extraction of the phycobiliproteins have been achieved with $0.05 \mathrm{mM}$ of phosphate buffer at $\mathrm{pH} 7$ at which phycobiliprotein are most stable near $\mathrm{pH} 7$ according to Mishra et al. (2010). In this study, following $65 \%$ ammonium sulphate precipitation, we have achieved 2.29 purity ratio (Table 3 ) for PC which is greater than that reported by Kumar et al. (2014) and 3.02 purity ratio (Table 4) for PE which is greater than that reported by Chakdar and Pabbi (2012).

Table 3. Estimation of spectroscopic purity and concentration of $\mathrm{PC}$

\begin{tabular}{|c|c|c|}
\hline & $\begin{array}{l}\text { PC crude } \\
\text { extract }\end{array}$ & $\begin{array}{c}65 \% \text { ammonium } \\
\text { sulphate precipitation }\end{array}$ \\
\hline$\overline{\text { Volume (mL) }}$ & 30 & 10 \\
\hline $\mathrm{OD}_{280}$ & 0.805 & 0.324 \\
\hline $\mathrm{OD}_{620}$ & 0.882 & 0.742 \\
\hline $\mathrm{OD}_{652}$ & 0.363 & 0.274 \\
\hline Conc. (mg/mL) & 0.132 & 0.114 \\
\hline Purity ratio & 1.0 & 2.2 \\
\hline
\end{tabular}

Table 4. Estimation of spectroscopic purity and concentration of $P E$

\begin{tabular}{lcc}
\hline & $\begin{array}{c}\text { PE crude } \\
\text { extract }\end{array}$ & $\begin{array}{c}\text { 65 \% ammonium } \\
\text { sulphate precipitation }\end{array}$ \\
\hline Volume $(\mathrm{mL})$ & 30 & 10 \\
OD $_{280}$ & 0.799 & 0.376 \\
$\mathrm{OD}_{562}$ & 1.336 & 1.136 \\
$\mathrm{OD}_{620}$ & 0.588 & 0.266 \\
$\mathrm{OD}_{652}$ & 0.422 & 0.213 \\
Conc. (mg/mL) & 0.125 & 0.111 \\
Purity ratio & 1.67 & 3.02 \\
\hline
\end{tabular}

The photosynthesis in cyanobacteria can dominate wide region ranged from 450 to $650 \mathrm{~nm}$ of solar spectrum due to the presence of colored protein-based pigments called phycobiliproteins, which are the family of the colored water soluble photosynthetic proteinacous pigments (Sonani et al., 2016). Phycobiliproteins are classifying according to their spectral properties. In this research, PC extracted from Nostoc linckia has $\lambda_{\mathrm{A} \max }=614$ $\mathrm{nm}$ as illustrated in Figure 1 and PE extracted from Nostoc carenum has $\lambda_{\mathrm{A} \max }=560 \mathrm{~nm}$ as illustrated in Figure 2 . The characteristic maximum absorbance wavelength of $(\mathrm{PC}) \lambda_{\mathrm{A}}$ ${ }_{\max }=610-620 \mathrm{~nm}$, allophycocyanin (APC) $\lambda_{\mathrm{A} \max }=650-$ $655 \mathrm{~nm}$ and (PE) $\lambda_{\mathrm{A} \max }=540-570 \mathrm{~nm}$ which are the majorly found phycobiliproteins (Singh et al., 2015).

\section{REFERENCES}

Abed, R. M. M.; Dobretsov, S. and Sudesh, K (2009). Applications of cyanobacteria in biotechnology. $J$. Appl. Microbiol. 106, 1-12.

Bennett, A. and Bogorad, L. (1973). Complementary chromatic adaptation in a filamentous blue-green alga. J. Cell Biol. 58, 419-435.

Bhadury, P. and Wright, P. C. (2004). Exploitation of marine algae: biogenic compounds for potential antifouling applications. Planta 219, 561-578.
Bornet, É. and Flahault, C. (1886). Revision des Nostocacées hétérocystées contenues dans les principaux herbiers de France. Annales des Sciences Naturelles, Botanique, Septième série 3, 323-381.

Castenholz, R. W. and Waterbury, J. B. (1989). In: J.T. Staley, M.P. Bryant, N. Pfennig and J.G. Holt [Eds] Bergey's Manual of Systematic Bacteriology. 3, 1710-1727 Williams \& Wilkins, Baltimore.

Chakdar, H. and Pabbi, S. (2012). Extraction and purification of phycoerythrin from Anabaena variabilis (CCC421). Phykos 42, 25 - 31.

Desikachary, T.V. (1959). Cyanophyta. ICAR , New Delhi, 1-686.

Gantt, E.; Lipschultz, C. A.; Grabowski, J. and Zimmerman, B. K. (1979). Phycobilisomes from blue-green and red algae: isolation criteria and dissociation characteristics. Plant Physiol. 63, 615 620.

Garcia-Pichel, F. and Pringault, O. (2001). Cyanobacteria track water in desert soils. Nature 413, 380-381.

Guerrero, M. G. and bra, C. (1987). Assimilation of inorganic nitrogen. In The Cyanobacteria. 163-186. Edited by I?. Fay \& C.Van Baalen. Amsterdam : Elsevier.

Hoshaw, R.W. and Rosowksi, J. R. (1973).Methods for microscopic algae. In handbook of phycological methods. Culture methods and growth measurements (Stein, J., editor), 53-07. Cambridge University Press, New York.

Hussein, M. H.; Soliman, A-R. I.; Dessouki, S. A. Sh. and Abdel-Samea, Y. T. (2000). Characterizaion of some nitrogen-fixing cyanobacteria used for soil algalization in Egypt. J. Union Arab Biol. Cairo 9B, 139-155.

Kumar, D.; Wattal Dhar, D.; Pabbi, S.; Kumar, N. and Walia, S. (2014). Extraction and purification of Cphycocyanin from Spirulina platensis (CCC540). Ind. J. Plant Physiol.19, 184-188.

Mishra, S. K.; Shrivastav, A.; Pancha, I.; Jain, D. and Mishra, S. (2010). Effect of preservatives for food grade C-Phycoerythrin, isolated from marine cyanobacteria Pseudanabaena sp. Int. J. Biol. Macromol. 47, 5.

Moreno, J.; Rodriguez, H.; Vargas, M. A.; Rivas, J. and Guerrero, M. G. (1995). Nitrogen - fixing cyanobacteria as source of phycobiliprotein pigments. Composition and growth performance of ten filamentous heterocystous strains. J. Appl. Phycol.7, 17-23.

Rippka, R.; Deruelles, J.; Waterbury, J.; Herdman, M. and Stanier, R. (1979).Generic assignments, strain histories and properties of pure cultures of cyanobacteria. J. Gen. Microbiol. 111, 1-61.

Schmidt, M.; Patel, A.; Zhao, Y. and Reuter, W. (2007). Structural basis for the photochemistry of aphycoerythrocyanin. Biochem. 46, 416-423.

Singh, N. K.; Sonani, R. R.; Rastogi, R. P. and Madamwar, D. (2015).The phycobilisomes: an early requisite for efficient photosynthesis in cyanobacteria. EXCLI J. 14, 268-289. 
Singh, R.; Parihar, P.; Singh, M.; Bajguz, A.; Kumar, J.; Singh, S.; Singh, V. P. and Prasad, S. M. (2017). Uncovering potential applications of cyanobacteria and algal metabolites in biology, agriculture and medicine: status and future prospects. Front. Microbiol. 8, doi: 10.3389/fmicb.00515.

Sonani, R. R.; Rastogi, R. P.; Patel, R. and Madamwar, D. (2016). Recent advances in production, purification and applications of phycobiliproteins. World J. Biol. Chem. 7,100-109.

Soni, B.; Kalavadia, B.; Trivedi, U. and Madamwar, D. (2006). Extraction, purification and characterization of phycocyanin from Oscillatoria qua dripunctulata - Isolated from the rocky shores of Bet-Dwarka, Gujarat, India. Process. Biochem. 41, 9.
Stainer, R. Y.; Kunisawa, R.; Mandel, M. and CohenBazire, G. (1971). Purification and properties of unicellular blue-green algae (Order Chroococcales). Bacteriol. Rev. 35, 171-205.

Tandeau de Marsac, N. (1977). Occurrence and nature of chromatic adaptation in cyanobacteria. J. Bacteriol. 130, 82-91.

Tandeau de Marsac, N. and Houmard, J. (1993).Adaptation of cyanobacteria to environmental stimuli: new steps towards molecular mechanisms. FEMS Microbio.l Rev. 104, 119-190.

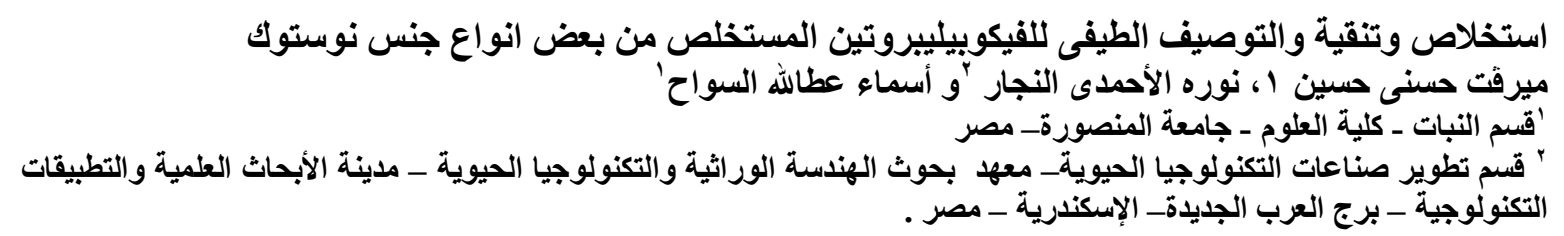

تتاول هذا البحث عزل نوعين من السيانوبكتريا وهما Nostoc linckia و Nostoc carneum حيث تم استخلاص صبغ

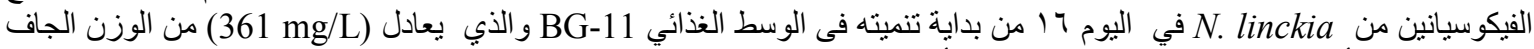

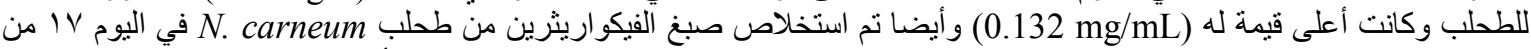

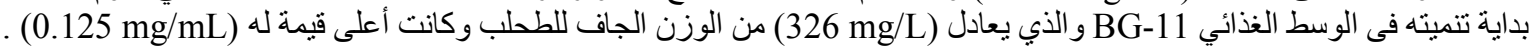

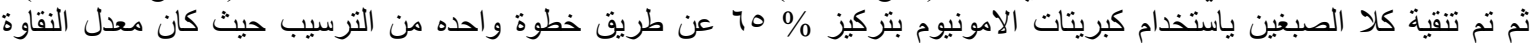

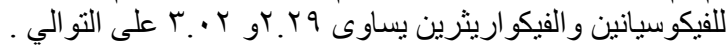

